\title{
HUBUNGAN KECEMASAN DENGAN KADAR GULA DARAH PADA PASIEN DIABETES MELITUS
}

\author{
Tri Wijayanto ${ }^{1}$, Widya $^{2}$ \\ ${ }^{1,2}$ Universitas Muhammadiyah Pringsewu \\ *E-mail : triwijayanto781@gmail.com
}

\begin{abstract}
Abstrak
Diabetes melitus merupakan penyakit kronis progresif akibat produksi insulin tidak adekuat yang menimbulkan ketidakmampuan tubuh melakukan metabolisme karbohidrat, protein dan lemak yang mengakibatkan kadar gula darah dalam tubuh meningkat diatas normal atau hiperglikemia. Salah satu faktor yang mempengaruhi kadar gula darah dalam tubuh adalah stress psikologis. Tujuan dalam penelitian ini adalah untuk diketahui hubungan kecemasan dengan kadar gula darah pada pasien diabetes melitus. Penelitian ini menggunakan metode survey analytic dengan pendekatan cross sectional. Populasi pada penelitian ini adalah pasien diabetes mellitus tipe 1 dan tipe 2 dengan jumlah sampel 81 orang, dan teknik sampling yang digunakan adalah consecutive sampling. Pengumpulan data pada penelitian ini mengunakan lembar observasi dan kuesioner kecemasan HRS-A. Uji statistic yang digunakan chi square. Hasil penelitian didapatkan bahwa sebagian besar responden mengalami kecemasan berat sebanyak 64,2 \% dan paling banyak responden dengan kadar gula darah tinggi $>200 \mathrm{mg} / \mathrm{dL}$ sebanyak 49,4\%. Ada hubungan kecemasan dengan kadar gula darah pada pasien diabetes melitus dengan $p$ value $0,025<\alpha \quad(0,05)$. Peneliti merekomendasikan kepada petugas kesehatan agar dapat memberikan edukasi kesehatan kepada pasien diabetes mellitus tentang proses penyakit diabetes melitus dan penatalaksanaannya untuk mengurangi kecemasan pada pasien diabetes mellitus sehingga kadar gula darah dapat terkontrol.
\end{abstract}

Kata kunci : Diabetes Melitus, Kadar Gula Darah, Kecemasan

\begin{abstract}
Diabetes mellitus is a chronic progressive disease due to inadequate insulin production which results in the inability of the body to metabolize carbohydrates, proteins and fats which causes blood sugar levels in the body to rise above normal or hyperglycemia. One of the factors that influence blood sugar levels in the body is psychological stress. The purpose of this study was to find out the relationship between anxiety and blood sugar levels in patients with diabetes mellitus. This study uses a survey analytic method with a cross sectional approach. The population in this study were type 1 and type 2 diabetes mellitus patients with a sample of 81 people, and the sampling technique used was consecutive sampling. Data collection in this study used the observation sheet and HRS-A anxiety questionnaire. Test the statistics used by chi square. The results showed that the majority of respondents experienced severe anxiety as much as $64.2 \%$ and most respondents with high blood sugar levels $>200 \mathrm{mg} / \mathrm{dL}$ as much as $49.4 \%$. There is a correlation between anxiety and blood sugar levels in patients with diabetes mellitus with $p$ value $0.025<\alpha(0.05)$. The researcher gave recommendations to health workers to be able to provide health education to patients with diabetes mellitus about the process of diabetes mellitus and its management to reduce anxiety in patients with diabetes mellitus so that blood sugar levels can be controlled.
\end{abstract}

Keywords: Diabetes Mellitus, Blood Sugar Levels, Anxiety 


\section{PENDAHULUAN}

Diabetes Melitus (DM) adalah penyakit kronis progresif yang ditandai dengan ketidakmampuan tubuh untuk melakukan metabolisme karbohidrat, lemak, dan protein yang mengarah ke peningkatan kadar gula darah diatas normal (hiperglikemia) (Black \& Hawk, 2013). Prevalensi global penderita DM diperkirakan untuk tahun 2015 dan 2040. Pada tahun 2015, prevalensi DM pada orang dewasa diperkirakan $\quad 8,8 \%$ sedangkan kelahiran hidup pada kehamilan dengan DM sekitar 16,2\%. Pada tahun 2040, prevalensi DM pada orang dewasa diperkirakan meningkat menjadi 10,4\%. Prevalensi DM terus meningkat di seluruh dunia (K. Ogurtsovaa et al., 2017). Angka kejadian diabetes melitus menurut data Riskesdas (2013) terjadi peningkatan dari 1,1\% di tahun 2007 menjadi 2,1 \% di tahun 2013 dari keseluruhan penduduk sebanyak 250 juta jiwa (Badan Penelitian dan Pengembangan Kesehatan Kementerian Kesehatan RI, 2013).

Diabetes melitus juga diklasifikasikan menjadi empat yakni DM tipe I, DM tipe II, diabetes gestasional, dan diabetes melitus yang berhubungan dengan kondisi lainnya. Manifestasi klinis pasien DM adalah peningkatan frekuensi urin (polyuria), peningkatan rasa haus (polydipsia) dan peningkatan masukan makanan (polyphagia) dengan penurunan berat badan (Smeltzer, 2010).
Komplikasi dini DM adalah ketoasidosis diabetik, dan hipoglikemia. Diabetes melitus yang kronik menimbulkan disfungsi atau kegagalan berbagai organ seperti mata, ginjal, saraf, jantung dan pembuluh darah serta mempengaruhi kondisi psikis (Black \& Hawk, 2013).

Menurut Perkeni/Perhimpunan Endokrinologi Indonesia (2015) ada lima pilar penanganan diabetes melitus, yakni edukasi kesehatan, diet, aktivitas fisik, obat-obatan, dan monitor kadar gula darah. Tujuan jangka pendek penanganan DM untuk menghilangkan keluhan atau gejala diabetes melitus dan mempertahankan rasa nyaman dan sehat, sedangkan tujuan jangka panjangnya adalah untuk mencegah timbulnya komplikasi baik makrovaskuler maupun neuropati yang tujuan akhirnya ialah menurunkan angka morbilitas dan mortalitas diabetes mellitus. Jika kelima pilar tersebut diterapkan dengan baik, maka komplikasi penyakit DM akan dapat dicegah dan kualitas hidup pasien DM akan menjadi lebih baik.

Penanganan pasien diabetes melitus juga dipengaruhi oleh faktor-faktor psikososial, yaitu faktor individu, faktor sosial dan faktor lingkungan. Sebagai contoh, faktor individu, misalnya efikasi diri, kontrol, koping, distres, kecemasan. Faktor sosial, misalnya dukungan, karakteristik keluarga, interaksi dengan profesional kesehatan, dan faktor lingkungan misalnya akses terhadap pusat kesehatan, 
hambatan dalam olahraga dan diet, serta faktor budaya (Stuart, 2008).

Kadar glukosa darah diatur melalui umpan balik negatif untuk mempertahankan keseimbangan di dalam tubuh. Kadar glukosa dalam darah dimonitor oleh pankreas, bila konsentrasi glukosa menurun karena digunakan untuk memenuhi energi tubuh, maka pankreas melepaskan glukagon, organ yang menargetkan sel-sel dihati. Kemudian sel ini merubah glikogen menjadi glukosa. Glukosa dilepaskan ke dalam aliran darah, hingga meningkatkan kadar gula. Kadar glukosa darah yang normal cenderung meningkat secara ringan tetapi bertahap setelah usia 50 tahun, terutama pada orang yang tidak aktif bergerak. Peningkatan kadar glukosa darah setelah makan atau minum merangsang pankreas untuk menghasilkan insulin sehingga mencegah kenaikan kadar glukosa darah yang lebih lanjut dan menyebabkan kadar glukosa darah menurun secara perlahan (PERKENI, 2015).

Pada keadaan normal glukosa darah di atur oleh insulin, sehingga kadarnya selalu dalam batas normal. Kadar gula darah rendah bila nilai GDS < $70 \mathrm{mg} / \mathrm{dl}$, kadar gula darah normal bila nilai GDS 70-199 mg/dl, dan kadar gula darah tinggi bila nilai GDS $\geq 200$ mg/dl. Pada keadaan DM tubuh relatif kekurangan insulin sehingga pengaturan kadar gula darah jadi kacau. Walaupun kadar gula darah tinggi, glukoneogenesis di hati tidak dapat dihambat sehingga menyebabkan nilai kadar gula darah semakin meningkat (PERKENI, 2015).

Glukosa darah sewaktu adalah pemeriksaan glukosa darah yang dilakukan setiap waktu sepanjang hari tanpa memperhatikan makanan terakhir yang dimakan dan kondisi tubuh orang tersebut, sedangkan pemeriksaan glukosa darah puasa adalah pemeriksaan glukosa yang dilakukan setelah pasien berpuasa selama 8-10 jam, sedangkan pemeriksaan glukosa 2 jam setelah makan adalah pemeriksaan yang dilakukan 2 jam dihitung setelah pasien menyelesaikan makan (Black \& Hawk, 2013).

Faktor-faktor yang mempengaruhi kadar gula darah adalah konsumsi karbohidrat, aktifitas fisik, penggunaan obat, keadaan sakit, stres psikologis, siklus menstruasi, dehidrasi, konsumsi alcohol. Pasien diabetes melitus memiliki tingkat stress yang tinggi dikarenakan penyakit yang dideritanya sehingga dapat mempengaruhi peningkatan kadar gula dalam darah, kondisi dimana kadar gula plasma pada waktu puasa $>140$ mg/dl, sedangkan kadar gula darah sewaktu $\geq 200$ mg/dl (Black \& Hawk, 2013).

Diagnosis diabetes mellitus akan meningkatkan stresor pada seseorang dimana stresor ini dapat menimbulkan kecemasan sehingga dapat menyebabkan kadar gula darah meningkat. Risiko terjadi kecemasan 
cenderung lebih tinggi pada orang yang menderita diabetes mellitus (Smelzer \& Bare, 2010).

Stres psikologis dapat dibagi menjadi empat yakni : cemas, marah, takut dan depresi. Kecemasan merupakan kondisi kegelisahan mental, keprihatinan, atau firasat atau perasaan putus asa karena ancaman yang akan terjadi atau ancaman antisipasi yang tidak dapat di identifikasi terhadap diri sendiri atau hubungan yang bermakna. Penderita diabetes melitus jika mengalami kecemasan, akan mempengaruhi proses kesembuhan dan menghambat kemampuan aktivitas kehidupan sehari-hari (Stuart, 2008).

Gejala fisik yang sering dialami jika seseorang mengalami kecemasan berat atau tinggi adalah penurunan tenaga, rasa cepat lelah dan sulit tidur yang dapat mempengaruhi perubahan pola makan. Sebagian besar orang mengeluh tidak nafsu makan, namun ada yang mengeluh bahwa makannya semakin tidak terkendali. Pada pasien diabetes melitus, keadaan ini tentunya akan mempengaruhi pola diet atau pola makan yang sudah ditetapkan. Pasien diabetes melitus yang mengalami kecemasan memiliki kontrol gula darah yang buruk dan meningkatnya gejala-gejala penyakit (Black \& Hawk, 2013).

Kecemasan merupakan hal yang tidak mudah untuk dihadapi oleh penderita diabetes melitus. Oleh karena itu, penderita diabetes melitus tentu sangat membutuhkan dukungan dari lingkungan sosialnya (Black \& Hawk, 2013). Jika terjadinya stress psikologis pada pasien diabetes mellitus, maka terjadi respon sistem saraf otonom sehingga menimbulkan aktivitas involunter pada tubuh yang termasuk dalam mekanisme pertahanan diri. Serabut saraf simpatis mengaktifkan tanda-tanda vital pada setiap tanda bahaya untuk mempersiapkan pertahanan tubuh. Kelenjar adrenal melepas adrenalin (epinefrin), yang menyebabkan tubuh mengambil lebih banyak oksigen, mendilatasi pupil, dan meningkatkan tekanan arteri serta frekuensi jantung, terjadi konstriksi pembuluh darah perifer dan memicu darah dari sistem gastrointestinal dan reproduksi serta meningkatkan glikogenolisis menjadi glukosa bebas guna menyokong jantung, otot, dan sistem saraf pusat. Glukosa yang telah didapat dari proses glikogenesis selanjutnya akan diubah menjadi karbohirat. Karbohidrat ini dapat masuk sirkulasi darah, sehingga menyebabkan kadar gula meningkat. Ketika bahaya telah berakhir, serabut saraf parasimpatis membalik proses ini dan mengembalikan tubuh ke kondisi normal sampai tanda ancaman berikutnya mengaktifkan kembali respons simpatis. Pasien diabetes melitus yang mengalami kecemasan memiliki kontrol gula darah yang buruk dan meningkatnya gejala-gejala penyakit (PERKENI, 2015). 
Teori ini sejalan dengan penelitian yang dilakukan Wiyadi (2013) di Ruang Flamboyan RS A. W Syahranie Samarinda terhadap 30 responden pasien diabetes mellitus didapatkan bahwa responden yang mengalami cemas berat sebanyak 15 orang (50\%), dan responden yang mengalami cemas sedang sebanyak 12 (40\%), dan responden yang mengalami cemas ringan sebanyak 3 $(10 \%)$ serta diperoleh nilai $\mathrm{p}=0,0011<\alpha$ $(0,05)$, hal ini menunjukan terdapat hubungan yang signifikan antara tingkat kecemasan dengan kadar gula darah (Wiyadi, 2013). Penelitian lain juga dilakukan oleh Ati, Suci dan Widaryati. (2014) di Rumah Sakit DKT Yogyakarta terhadap 51 responden didapatkan hasil uji bivariat nilai p $0,008<\alpha(0,05)$ menunjukan adanya hubungan kecemasan dengan kadar gula darah pada pasien diabetes mellitus (Ati, 2014).

Pasien diabetes melitus membutuhkan penanganan yang adekuat guna menyembuhkan gejala maupun mencegah timbulnya komplikasi lebih lanjut. Sebagain besar penderita diabetes melitus akan mengalami stress psikologis dikarenakan proses penyakit yang diderita pasien sehingga kecemasan tersebut dapat mempengaruhi peningkatan kadar gula dalam darah. Adapun tujuan penelitian ini adalah diketahuinya hubungan kecemasan dengan kadar gula darah pada pasien diabetes melitus di Rumah Sakit Mitra Husada Pringsewu Lampung tahun 2017.

\section{METODOLOGI}

Desain penelitian yang digunakan adalah survey analytic dengan pendekatan cross sectional. Populasi penelitian ini adalah pasien diabetes melitus tipe 1 dan tipe 2 dengan jumlah sampel sebanyak 81 pasien. Teknik sampling yang digunakan adalah consecutive sampling. Waktu penelitian dilakukan pada minggu pertama bulan Juli sampai minggu pertama bulan Agustus 2017 dan tempat penelitian di ruang rawat inap dan rawat jalan Rumah Sakit Mitra Husada Pringsewu Lampung.

Alat yang digunakan untuk mengukur kecemasanan dengan skala HAR'S (Hamilton Rating Scale For Anxiety) yang telah baku, dan lembar observasi pengukuran kadar gula dasar sewaktu (GDS) dan alat yang digunakan untuk mengukur GDS adalah glukometer atau Glucose Cholesterol Urid Acid (GCU) yang sudah dikalibrasi. Analisis data yang digunakan dalam penelitian ini yaitu analisis univariat untuk mendeskripsikan distribusi frekuensi karakteristik responden berdasarkan usia, pekerjaan, pendidikan, jenis kelamin, lama menderita diabetes melitus, kadar gula darah, dan tingkat kecemasan. Sedangkan analisis bivariat untuk menganalisis hubungan kecemasa dengan kadar gula darah pasien diabetes mellitus dengan menggunakan uji statistic person chi square dengan $\alpha=0,05$. 


\section{HASIL}

\section{Analisis Univariat}

a. Karakteristik Responden berdasarkan umur

Tabel 1 Distribusi frekuensi karakteristik responden berdasarkan umur di Rumah Sakit Mitra Husada Pringsewu Lampung tahun 2017

\begin{tabular}{ccc}
\hline Umur & Jumlah & $\begin{array}{c}\text { Persentase } \\
(\%)\end{array}$ \\
\hline $26-45$ & 31 & 38,3 \\
$46-65$ & 50 & 61.7 \\
Total & 81 & 100 \\
\hline
\end{tabular}

Tabel 1 didapatkan bahwa karakteristik responden berdasarkan umur sebagian besar berumur 46-65 tahun sebanyak $50(61,7 \%)$.

b. Karakteristik responden berdasarkan jenis kelamin

Tabel 2. Distribusi frekuensi karakteristik responden berdasarkan jenis kelamin di Rumah Sakit Mitra Husada Pringsewu Lampung tahun 2017

\begin{tabular}{lcc}
\hline Jenis Kelamin & Jumlah & Persentase (\%) \\
\hline Laki-laki & 36 & 44.4 \\
Perempuan & 45 & 55,6 \\
$\quad$ Total & 81 & 100 \\
\hline
\end{tabular}

Tabel 2 didapatkan bahwa karakteristik responden berdasarkan jenis kelamin sebagian besar berjenis kelamin perempuan sebanyak $45(55,6 \%)$.

c. Karakteristik responden berdasarkan pendidikan

Tabel 3. Distribusi frekuensi karakteristik responden berdasarkan tingkat pendidikan di Rumah Sakit Mitra Husada Pringsewu Lampung tahun 2017

\begin{tabular}{lccc}
\hline \multicolumn{1}{c}{ Pendidikan } & Jumlah & Persentase (\%) \\
\hline SD & & 26 & 32,1 \\
SMP & 11 & 13,6 \\
SMA & & 44 & 54,3 \\
& Total & & \\
\hline
\end{tabular}

Tabel 3 didapatkan bahwa karakteristik responden berdasarkan tingkat pendidikan sebagian besar SMA sebanyak $44 \quad(54,3 \%)$ responden.

d. Karakteristik responden berdasarkan pekerjaan

Tabel 4. Distribusi frekuensi karakteristik responden berdasarkan pekerjaan di Rumah Sakit Mitra Husada Pringsewu Lampung tahun 2017

\begin{tabular}{|c|c|c|}
\hline Pekerjaan & Jumlah & Persentase $(\%)$ \\
\hline IRT & 20 & 24,7 \\
\hline Petani & 21 & 25,9 \\
\hline Buruh & 13 & 16,0 \\
\hline Pedagang & 12 & 14,8 \\
\hline Swasta & 14 & 17,3 \\
\hline Tidak Bekerja & 1 & 1,2 \\
\hline Total & 81 & 100 \\
\hline
\end{tabular}

Tabel 4 didapatkan bahwa karakteristik responden berdasarkan pekerjaan paling banyak sebagai petani sebanyak 21 $(25,9 \%)$.

e. Karakteristik responden berdasarkan lama menderita DM

Tabel 5. Distribusi frekuensi karakteristik responden berdasarkan lama menderita DM di Rumah Sakit Mitra Husada Pringsewu Lampung tahun 2017

\begin{tabular}{|c|c|c|}
\hline $\begin{array}{l}\text { Lama } \\
\text { Menderita }\end{array}$ & Jumlah & Persentase $(\%)$ \\
\hline 1 Tahun & 12 & 14,8 \\
\hline 2 Tahun & 13 & 16.0 \\
\hline 3 Tahun & 13 & 16.0 \\
\hline 4 Tahun & 18 & 22,2 \\
\hline 5 Tahun & 10 & 12,3 \\
\hline 6 Tahun & 10 & 12,3 \\
\hline 7 Tahun & 5 & 6,2 \\
\hline Total & 81 & 100 \\
\hline
\end{tabular}

Tabel 5 didapatkan bahwa karakteristik responden berdasarkan lamanya menderita diabetes melitus paling banyak 4 tahun sebanyak $18(22,2 \%)$. 


\section{f. Kecemasan}

Tabel 6 Distribusi frekuensi kecemasan pada pasien diabetes mellitus di RS Mitra Husada Pringsewu Lampung tahun 2017

\begin{tabular}{lcc}
\hline Kecemasan & Jumlah & Persentase (\%) \\
\hline Sedang & 29 & 35,8 \\
Berat & 52 & 64,2 \\
Total & 81 & 100 \\
\hline
\end{tabular}

Tabel 6 didapatkan bahwa sebagian besar responden memiliki kecemasan berat sebanyak $52(64,2 \%)$ dan kecemasan sedang sebanyak $29(35,8 \%)$.

\section{g. Kadar Gula Darah}

Tabel 7 Distribusi frekuensi kadar gula darah pada pasien diabetes mellitus di RS Mitra Husada Pringsewu Lampung tahun 2017

\begin{tabular}{|c|c|c|}
\hline Kadar Gula darah & Jumlah & $\begin{array}{c}\text { Persentase } \\
(\%)\end{array}$ \\
\hline Rendah $<70 \mathrm{mg} / \mathrm{dL}$ & 19 & $23,5 \%$ \\
\hline $\begin{array}{l}\text { Normal } \\
\mathrm{mg} / \mathrm{dL}\end{array}$ & $\begin{array}{l}22 \\
40\end{array}$ & $\begin{array}{l}27,2 \% \\
49,4 \%\end{array}$ \\
\hline \multicolumn{3}{|l|}{ Tinggi $\geq 200 \mathrm{mg} / \mathrm{dL}$} \\
\hline Total & 81 & $100 \%$ \\
\hline
\end{tabular}

Tabel 7 didapatkan hasil bahwa responden yang memiliki kadar gula darah dengan kategori rendah $<70 \mathrm{mg} / \mathrm{dL}$ sebanyak 19 $(23,5 \%)$, kadar gula darah dengan kategori normal 70-199 mg/dL sebanyak 22 $(27,2 \%)$, dan kadar gula darah dengan kategori tinggi $\geq 200 \mathrm{mg} / \mathrm{dL}$ sebanyak 40 $(49,4 \%)$.

\section{Analisis Bivariat}

Analisis bivariat menggunakan chi square untuk mengetahui hubungan kecemasan dengan kadar gula darah pada pasien diabetes mellitus di Rumah Sakit Mitra Husada Kabupaten Pringsewu 2017.
Tabel 8 Distribusi frekuensi hubungan kecemasan dengan kadar gula darah pada pasein diabetes melitus di Rumah Sakit Mitra Husada Kabupaten Pringsewu Lampung 2017

\begin{tabular}{|c|c|c|c|c|c|c|c|c|}
\hline \multirow{3}{*}{ Cemas } & \multicolumn{6}{|c|}{ Kadar Gula Darah Sewaktu } & \multirow{3}{*}{ Total } & $\mathrm{P}$ \\
\hline & \multicolumn{2}{|c|}{ Rendah } & \multicolumn{2}{|c|}{ Normal } & \multicolumn{2}{|c|}{ Tinggi } & & CI \\
\hline & $\mathrm{N}$ & $\%$ & $\mathrm{~N}$ & $\%$ & $\mathrm{~N}$ & $\%$ & & \\
\hline Sedang & 11 & $\begin{array}{c}57 \\
.9\end{array}$ & 9 & $\begin{array}{c}40 . \\
9\end{array}$ & 9 & 22.5 & 29 & \\
\hline Berat & 8 & $\begin{array}{c}42 \\
.1\end{array}$ & 13 & $\begin{array}{c}59 . \\
1\end{array}$ & 31 & 77.5 & 52 & $\begin{array}{c}0.02 \\
5\end{array}$ \\
\hline Total & 19 & $\begin{array}{c}10 \\
0\end{array}$ & 22 & $\begin{array}{c}10 \\
0\end{array}$ & 40 & 100 & 81 & \\
\hline
\end{tabular}

Berdasarkan tabel 8 hasil analisis bivariat diketahui bahwa dari 52 responden dengan kecemasan berat memiliki kadar GDS tinggi sebanyak 31 orang $(77.5 \%)$, sedangkan dari 29 responden dengan kecemasan sedang memiliki kadar GDS rendah sebanyak 11 orang (57.9\%). Hasil uji statistik person chi square didapat nilai $\mathrm{p} \alpha$ value 0,025 yang < 0,05 . Artinya dapat disimpulkan bahwa ada hubungan kecemasan dengan kadar gula darah sewaktu pada pasein diabetes melitus di Rumah Sakit Mitra Husada Kabupaten Pringsewu 2017.

\section{PEMBAHASAN}

Hasil penelitian didapatkan bahwa sebagian besar responden memiliki kecemasan berat sebanyak 52 (64,2\%). Stuart (2008) membagi kecemasan menjadi empat jenis, yaitu kecemasan ringan, kecemasan sedang, kecemasan berat, dan panic. Cemas merupakan salah satu manifestasi dari stress, dengan mekanisme koping yang tidak disadari. Koping tersebut dapat membantu dan dapat menjadi penghalang, tergantung 
pada situasi dan lama waktu mekanisme tersebut digunakan atau dialami. Oleh karena itu pada pasien diabetes melitus diperlukan koping individu yang baik agar tidak terjadi kecemasan.

Beberapa faktor yang dapat mempengaruhi kecemasan adalah status kesehatan. Seseorang yang sedang sakit dapat menurunkan kapasitas seseorang dalam menghadapi stress. Diagnosis diabetes mellitus akan meningkatkan stresor pada seseorang dimana stresor ini dapat menimbulkan kecemasan sehingga dapat menyebabkan kadar gula darah meningkat. Risiko terjadi kecemasan cenderung lebih tinggi pada orang yang menderita diabetes mellitus. Pendidikan kesehatan tentang proses penyakit, komplikasi dan penanganan DM dapat berperan penting terjadinya kecemasan pada pasien DM. Kecemasan merupakan hal yang tidak mudah untuk dihadapi oleh penderita diabetes melitus. Oleh karena itu, penderita diabetes melitus tentu sangat membutuhkan dukungan keluarga, orang terdekat, atau rekan kerja dan lingkungan sosialnya. Kecemasan pada pasien DM dapat bervariasi mulai dari tingkat ringan sampai dengan berat, dan bahkan panic tetapi jarang. Faktor lainnya yang dapat mempengaruhi kecemasan pada pasien DM adalah tipe kepribadian, makna yang dirasakan, nilai-nilai budaya dan spiritual.

Penelitian yang dilakukan Wiyadi (2013) di Ruang Flamboyan RS A.Wahab Syahranie Samarinda terhadap 30 responden tentang hubungan tingkat kecemasan dengan kadar gula darah pada pasien diabetes melitus didapatkan hasil sebagian besar (50\%) responden mengalami kecemasan berat.

Peneliti berpendapat bahwa sebagian besar pasien DM di RS Mitra Husada mengalami kecemasan berat disebabkan oleh beberapa factor yaitu status kesehatan. Seseorang yang menderita DM memiliki stressor yang tinggi terutama komplikasi yang akan terjadi selanjutnya sehingga menimbulkan kecemasan. Pasien DM yang kurang mendapatkan pendidikan kesehatan tentang proses penyakit, komplikasi dan penanganan DM berpeluang tinggi mengalami kecemasan. Kurangnya dukungan keluarga, orang terdekat atau rekan kerja dan lingkungan sangat mendukung terjadinya kecemasan pasien DM.

Hasil penelitian didapatkan bahwa paling banyak responden memiliki kadar gula darah tinggi $\geq 200 \mathrm{mg} /$ sebanyak 40 (49,4\%). Menurut Smeltzer \& Bare (2008) glukosa darah merupakan bentuk karbohidrat yang paling sederhana diabsorbsi ke dalam cairan darah melalui pencernaan. Kadar glukosa darah (KGD) ini akan meningkat setelah makan dan biasanya akan turun pada level yang paling rendah pada pagi hari sebelum orang makan. Kadar glukosa darah diatur melalui umpan balik negatif untuk mempertahankan keseimbangan di dalam tubuh. Kadar glukosa dalam darah dimonitor 
oleh pankreas, bila konsentrasi glukosa menurun karena dikonsumsi untuk memenuhi energi tubuh, pankreas melepaskan glukagon, organ yang menargetkan sel-sel dihati. Kemudian sel ini merubah glikogen menjadi glukosa. Glukosa dilepaskan ke dalam aliran darah, hingga meningkatkan kadar gula. Pada keadaan normal glukosa darah di atur sedemikian oleh insulin, sehingga kadarnya selalu dalam batas normal. Pada keadaan DM tubuh relatif kekurangan insulin sehingga pengaturan KGD jadi kacau. Walaupun KGD tinggi, glukoneogenesis di hati tidak dapat dihambat sehingga menyebabkan nilai KGD semakin meningkat. Kadar glukosa darah yang normal cenderung meningkat secara ringan tetapi bertahap setelah usia 50 tahun, terutama pada orang yang tidak aktif bergerak. Peningkatan kadar glukosa darah setelah makan atau minum merangsang pankreas untuk menghasilkan insulin sehingga mencegah kenaikan kadar glukosa darah yang lebih lanjut dan menyebabkan kadar glukosa darah menurun secara perlahan .

Sejalan dengan penelitian Ati, Suci dan Widaryati (2014) di Rumah Sakit DKT Yogyakarta tentang hubungan antara kecemasan dengan kadar gula darah pada pasien diabetes melitus terhadap 51 responden diperoleh hasil bahwa sebagian besar pasien memiliki kadar gula darah $\geq 200 \mathrm{mg} / \mathrm{dL}$ sejumlah $41(80,4 \%)$ responden.
Peneliti berpendapat bahwa pada pasien diabetes melitus dianjurkan dapat mengontrol kadar gula darahnya dengan cara dapat mengatur pola makan dan tidak terlalu banyak beban pikiran sehingga dapat meningkatkan kadar gula darah. Ketat dalam menjalankan lima pilar penangan DM yakni meningkatkan pemahaman tentang penyakit DM dengan mengikuti penyuluhanpenyuluhan yang diadakan oleh tenaga kesehatan sehingga dengan adanya pengetahuan yang lebih tentang DM diharapkan penderita DM tidak mengalami kecemasan yang berlebihan yang akhirnya berdampak pada peningkatan kadar gula darah. Perencanaan diet atau makanan diperlukan sesuai kebutuhan penderita DM sehingga kadar gula dapat senantiasa terkontrol.

Aktifitas fisik atau olahraga teratur oleh penderita DM dimaksudkan agar penderita DM dapat menjaga kebugaran tubuh juga memperbaiki sensitivitas insulin. Penggunaan obat-obatan penurun gula darah perlu diberikan jika tidak berhasil dengan pengaturan diet dan aktifitas fisik. Monitoring gula darah pada penderita DM harus senantiasa dipantau agar mengetahui dosis pemberian obat sudah sesuai atau belum dan penderita dapat mengontrol kadar gula darahnya setiap hari.

Hasil analisis bivariat uji statistik person chi square diperoleh nilai $\mathrm{p} \alpha$ value 0,025 yang < 
0,05, artinya ada hubungan kecemasan dengan kadar gula darah pada pasein diabetes melitus di Rumah Sakit Mitra Husada Kabupaten Pringsewu 2017.

Penderita DM memiliki tingkat depresi dan kecemasan yang tinggi, yang berkaitan dengan pengobatan yang harus dijalani dan terjadinya komplikasi serius. Kecemasan yang dialami penderita berkaitan dengan pengobatan yang harus dijalani seperti diet atau pengaturan makan, pemeriksaan kadar gula darah, konsumsi obat dan juga olah raga. Risiko komplikasi penyakit yang dialami penderita menyebabkan terjadinya kecemasan. Respon sistem saraf otonom terhadap rasa takut dan ansietas menimbulkan aktivitas involunter pada tubuh yang termasuk dalam mekanisme pertahanan diri. Serabut saraf simpatis mengaktifkan tanda-tanda vital pada setiap tanda bahaya untuk mempersiapkan pertahanan tubuh.

Di samping itu kelenjar adrenal melepas adrenalin (epinefrin), yang menyebabkan tubuh mengambil lebih banyak oksigen, mendilatasi pupil, dan meningkatkan tekanan arteri serta frekuensi jantung sambil membuat konstriksi pembuluh darah perifer dan memicu darah dari sistem gastrointestinal dan reproduksi serta meningkatkan glikogenolisis menjadi glukosa bebas guna menyokong jantung, otot, dan sistem saraf pusat. Glukosa yang telah didapat dari proses glikogenesis selanjutnya akan diubah menjadi karbohirat.
Karbohidrat ini dapat masuk ke sirkulasi darah, sehingga menyebabkan kadar gula meningkat. Ketika bahaya telah berakhir, serabut saraf parasimpatis membalik proses ini dan mengembalikan tubuh ke kondisi normal sampai tanda ancaman berikutnya mengaktifkan kembali respons simpatis.

Menurut Stuart (2008), rentang respon induvidu terhadap cemas berfluktuasi antara respon adaptif dan maladaptif. Rentang respon yang paling adaptif adalah antisipasi dimana individu siap siaga untuk beradaptasi dengan cemas yang mungkin muncul. Sedangkan rentang yang paling maladaptif adalah panik dimana individu sudah tidak mampu lagi berespon terhadap cemas yang dihadapi sehingga mengalami ganguan fisik dan psikososial.

Hasil penelitian Wiyadi (2013) tentang hubungan tingkat kecemasan dengan kadar gula darah pada pasien diabetes mellitus diruang Flamboyan RS. A.W Syahranie Samarinda diperoleh $\rho$ a value sebesar 0,021 $<0,05$.

Peneliti berpendapat bahwa kecemasan pasien DM di Rumah Sakit Mitra Husada dapat disebabkan oleh beberapa factor, seperti pengobatan yang harus dijalani (minum obat diabetikum, olah raga, diet, monitoring kadar gula darah), dan kemungkinan komplikasi serius yang akan terjadi akibat penyakit tersebut. Kecemasan yang berkelanjutan akan 
menyebabkan rangsangan terhadap system saraf otonom yang menimbulkan aktivitas involunter pada tubuh termasuk mekanisme pertahanan tubuh, dan perubahan tanda-tanda vital.

Kecemasan akan merangsang kelenjar adrenal melepas adrenalin (epinefrin), yang menyebabkan tubuh mengambil lebih banyak oksigen, mendilatasi pupil, dan meningkatkan tekanan arteri serta frekuensi jantung sambil membuat konstriksi pembuluh darah perifer dan memicu darah dari sistem gastrointestinal dan reproduksi serta meningkatkan glikogenolisis menjadi glukosa bebas guna menyokong jantung, otot, dan sistem saraf pusat. Glukosa yang telah didapat dari proses glikogenesis selanjutnya akan diubah menjadi karbohirat. Karbohidrat ini dapat masuk kealiran darah, sehingga menyebabkan kadar gula meningkat. Ketika bahaya telah berakhir, serabut saraf parasimpatis membalik proses ini dan mengembalikan tubuh ke kondisi normal sampai tanda ancaman berikutnya mengaktifkan kembali respons simpatis .

Peran petugas kesehatan dapat memberian pendidikan kesehatan pada pasien diabetes tentang penyakit DM, pengendalian dan pemantuan penyakit DM, pengobatan secara farmakologis dan non farmakologis, komplikasi DM (hipoglikemi dan hiperglikemi), perawatan kaki. Dengan diberikan pendidikan kesehatan tersebut pasien dapat memahami dan melaksanakan program penatalaksanaa DM sehingga dapat menurunkan kecemasan dan memperlambat atau mencegah terjadinya komplikasi akibat DM yang kronik.

\section{KESIMPULAN}

Sebagian besar pasien diabetes melitus mengalami kecemasan berat sebanyak 52 $(64,2 \%)$. Sebagian besar pasien diabetes melitus memiliki kadar gula darah $\geq 200$ mg/dL sebanyak 40 (49,4\%). Ada hubungan kecemasan dengan kadar gula darah pada pasien diabetes melitus di Rumah Sakit Mitra Husada Kabupaten Pringsewu Lampung tahun 2017 dengan p value $(0,025)<\alpha(0,05)$.

\section{KEPUSTAKAAN}

Ati, S. d. W. (2014). Hubungan Antara Kecemasan dengan Kadar Gula Darah pada Pasien Diabetes Melitus di Rumah Sakit DKT Yogyakarta. Skripsi thesis, STIKES 'Aisyiyah Yogyakarta. Retrieved from http://digilib.unisayogya.ac.id

Badan Penelitian dan Pengembangan Kesehatan Kementerian Kesehatan RI. (2013). Penyajian Pokok-Pokok Hasil Riset Kesehatan Dasar 2013.

Black, J. M., \& Hawk, J. H. (2013). Medical surgical nursing clinical management for positive outcome (Vol. 7th Ed). Philadelphia: Mosbi.

K. Ogurtsovaa, et al. (2017). IDF Diabetes Atlas: Global estimates for the prevalence of diabetes for 2015 and 2040. Diabetes Research And Clinical Practice, Volume 128. Retrieved from https://www.diabetesresearchclinicalpra ctice.com/article/s0168-8227(17)30375$\underline{\text { 3/fulltext }}$ 
PERKENI. (2015). Konsensus pengelolaan dan pencegahan diabetes melitus tipe 2 di Indonesia 2015, .

Smeltzer, S. C. B., Brenda G., (2010), (2010). Brunner \& Suddarth's Textbook of Medical-Surgical Nursing, (10th edition, ed.). Lippincott Williams \& Wilkin,.

Stuart, G. W. (2008). Buku Saku Keperawatan Jiwa (Edisi 5 ed.). Jakarta: Penerbit EGC.

Wiyadi. (2013). Hubungan tingkat kecemasan dengan kadar gula darah pada penderita diabetes mellitus. Jurnal Husada Mahakam. Kalimantan Timur. Retrieved from http://husadamahakam.poltekkeskaltim.ac.id/ojs 